\title{
Improving students' performance by means of motivation: the role of ICTs
}

\author{
Javier NOVO-HERNANZ \\ Universidade da Coruña - Spain \\ Xose PICATOSTE
}

\section{Universidad Autónoma de Madrid - Spain}

\begin{abstract}
:
Aim: The main objective of this paper is to analyze the effects of educational innovation on student implication on the study as a way for getting a job in the future, as well as the role of motivation at the secondary school to help for achieving this goal.

Design / Research methods: By means of the elaboration of a questionnaire, the opinion of the students in relation to educative innovation, and, later by means of descriptive statistical analysis and a regression analysis, to search the relation between the concerns for getting a job and the motivational education among the students in secondary educative level is undertaken.
\end{abstract}

Conclusions / findings: The results point towards a positive assessment by the students, who consider that educational innovation, stimulates their interest; boost the participation and collaboration between peers and with the teaching staff, at the same time there is a statistical significant relation between the students' concern about their future working life and the motivations at school. The motivation is strongly relate to incorporation of ICTs at classroom, particularly computers and tablets.

Originality / value of the article: The main value of this research is on stablishing a link between three key features: the concerns of youth about their future labor life, the motivation at school and the role of ICTs on this motivation.

Limitations: The main limitations of this research are related to the sample, nevertheless the preliminary generalization of this results can be acceptable, according the literature.

Keywords: educative innovation, students, motivation

JEL: I21, I28, O38

Correspondence address: Javier Novo-Hernanz, Universidade da Coruña, Spain. E-mail: javier.novo.hernanz@gmail.com, Xose Picatoste, Universidad Autónoma de Madrid, Spain. E-mail: xose92@gmail.com

Received: 13.07.2018, Revised: 07.03.2019, Accepted: 08.03.2019

doi: http://dx.doi.org/10.29015/cerem.754 


\section{Introduction}

The students' performance is a key matter not only for the development of individuals as well as society welfare and countries progress. At the same time, it constitutes part of the basis for more just, equalitarian and advanced societies, with a greater personal and social well-being. The fast and great technological advancements should be taken account, since they can be a strong tool for helping in achieving studding competences, but also because it is needed to know and manage them in order to get a job position. These challenges require constant updating in the field of the Information and Communication Technologies (ICTs) (Novo-Corti et al. 2013). This is pointing out to the necessary social and educational innovation. The efforts of teachers and students sometimes are not visible in the expected results, due to multiple reasons, among which are the lack of student motivation.

The students who currently attending secondary education think and process the information in a way which is substantially different to the young people of previous generations (Prensky 2001, 2011). These students are not just digital natives or "millennials", they are people who have overcome these two denominations and who face the age of artificial intelligence and robotization. On the other hand, teachers usually belong to another generation, mostly of "digital immigrants", that is, they have been trained in a different context and have gradually adapted to new digital environments and adopted ICTs as a daily tool. In this way, it is very likely that the ideal methodology for learning will probably be different from the points of view of one and the other, since each one has their own perspective and opinion.

According to Gagne $(1965,1971,1984)$, learning consists in a change of the human disposition or capacity, with a character of relative permanence and that is not attributable simply to the development process. But the environment in which this learning takes place evolves and in the last decades have faced changes so substantial that they have been configured as the "technological revolution". These disruptive changes must also be addressed by both students and teachers because they affect not only the learning process but also the teaching process (Gagne, Briggs 1979). The academic success will depend very much on these adaptations to the new environment. In this process, the motivation of the student, in relation to the 
processes of educational innovation, is a central issue, which constitutes the object of study of this work.

Although "digital natives" students are self-motivated, committed, have great ICT skills and skilfully navigate virtual networks, it is essential to promote a carefully designed pedagogy not only to increase student participation, but also selforientation, so that this leads to a higher academic performance (Hyland, Kranzow 2011). The situation is complex and requires imaginative solutions that incorporate ICTs and at the same time be effective and effective from the pedagogical point of view.

In this work, we analyze the effects of educational innovation on student motivation, in the context of secondary education. By means of the elaboration of a questionnaire, the opinion of the students in relation to educative innovation, and, later by means of the appropriate statistical methods, a comparative analysis between the different groups of students in secondary educative level is undertaken. The ANOVA analysis help us to get results and conclusions to drive some implications for improving scholar performance and, then increasing the possibilities of getting a better job for the young people.

The structure of this paper is as follows: the next section presents a revision of literature about the motivation of students at school and its influence on the performance as the first step for getting a job. The third section explain the method and the design of this research, the forth one show the results and then a discussion section is presented, previously to the main conclusions achieved in this work. A last section explain the main limitations of this work, which finish with the references section.

\section{Motivation, performance and results: the first step for getting a job}

According to Sini, Muzzulini, Schmidt and Tinti (2018) the motivation is an internal process that explains one's actions towards an objective. This concept is related to the impulses or inclinations to do something to achieve an objective (in this case a way to learn and get a good job in the future), therefore the study of 
motivation is certainly complex (Atkinson 1964). Although there are many theories of learning and motivation that explain certain aspects of behavior (Schunk et al. 2008), it is social cognitive theory that is considered more complete. Social cognitive theory was designed to explain how people acquire competencies, attitudes, values, behaviour styles and how they motivate and regulate their level of working or their effort (Bandura 2006). Social cognitive theory has been developed by Bandura $(1986,2001,2005)$ and extended by other authors (such as Pajares, Schunk 2001; Pintrich 2003), explains human learning and motivation in terms of reciprocal interactions that they involve personal characteristics (for example, intrinsic motivation, self-efficacy and self-determination), environmental contexts (e.g. high school) and behaviour (e.g. enrolling in advanced science courses) (Donaldson 2012). Motivation is defined in social cognitive theory as an internal state that awakens, directs and sustains goal-oriented behavior (Bryan et al. 2011). There is also a relationship between motivation and job and satisfaction. Then there is a possibility of finding subjects motivated towards work but dissatisfied. The search for a job as well as satisfaction is an important goal for youth (García Sedeño et al. 2003).

Social relationships are very important in motivation (García Sedeño et al. 2003) have found that when subjects start in a certain work activity, their motivation is focused mainly on those aspects of work related to personal relationships, opportunities for achievement, personal development and professional, and the search for situations that increase their self-concept, all extrinsic aspects. In addition, they have shown that the possibility of generating expectations about the stability of employment with respect to the work performed, increases the levels of motivation in carrying out the work. Although all these aspects refer to working life, they are related to the sphere of the individual and, therefore, to his general life trajectory and to his student age in particular. Vital experiences are manifested in the labor field, so that, in some way, the loss of centrality of work in the constitution of youth social identities and certain changes in values, aspirations, and attitudes lead to the argument that certain young people show scant motivation to work. The multiple aspects in the trajectories of youth in their incorporation to labor market are linked to the diagnosis of the juvenile labor situation and also related to their way of 
addressing the problems for labor integration from their training needs to dispositions towards employment (Jacinto 2008). Pérez (2013) has studied the implementation of vocational training programs, based on a diagnosis focused on the youth's lack of employability in relation to their scarce and inadequate training and found that their attitude was an essential characteristic.

\section{Method and design}

The design is based on a quantitative case study (D'Ancona, Ángeles 1999), trying to know the students motivation in relation to the innovative procedures at the school and its relationship with possibilities of getting a job by means of learning and getting knowledge and skills to improve their employability. A questionnaire was developed and distributed among students of one single high school, trying to minimize the differences among students and focus specifically on their attitudes towards innovation as a way to improve their motivation for improving their capabilities in general and their opportunities to get a job in particular. The main questions of this surveys are shown in Table 1. The questions were statements that should be assessed by the students. A 5-point Likert Scale was used, where the values where: 1. I absolutely disagree, 2. I disagree, 3. I'm indifferent, neither agree nor disagree, 4. I Agree, 5. I absolutely agree. So, the higher values, the higher will the agreement.

The questionnaire was previously validated, asking to some experts, some pedagogical researchers and teachers at different courses in Secondary Education Level. A pretest was conducted among a group of volunteer students. After reformulating the first version of our questions, we became to the final questionnaire, shown in Table 1.

The questionnaires were printed and given to the students at the end of a normal class. The teacher explained the main objective of the tests and give the opportunity to reject participating in the survey. Most of students were excited with this research and none of them refused to cover the questionnaire. More than 60 responses were 
collected. Once the wrong and incomplete items were removed, 56 valid responses were considered for this study, then, the sample size consist of 56 students.

A lineal regression analysis was proposed, where the "Concern on future labor integration" was the endogenous variable and the exogenous ones were Attitude of the student towards learning, Teachers attitude, Attitude of the student towards educative innovation and the student's perspective about ICTs for motivation at classroom.

Table 1. Questionnaire

\begin{tabular}{|l|l|}
\hline Area & Question \\
\hline $\begin{array}{l}\text { Concern on future labor } \\
\text { integration }\end{array}$ & $\begin{array}{l}\text { Study to progress in the future and increase my } \\
\text { opportunities of getting a good job }\end{array}$ \\
\hline Attitude towards learning & I enjoy learning \\
\hline $\begin{array}{l}\text { Teachers attitude towards } \\
\text { motivation }\end{array}$ & $\begin{array}{l}\text { I'm motivated by teachers who do innovative activities in } \\
\text { class }\end{array}$ \\
\hline $\begin{array}{l}\text { Attitude towards educative } \\
\text { innovation }\end{array}$ & I feel better in class if the faculty uses new technologies \\
\hline $\begin{array}{l}\text { ICTs for motivation at } \\
\text { classroom }\end{array}$ & Using tablets or computers in class motivates me \\
\hline
\end{tabular}

Source: authors' own elaboration.

\section{Results}

The results are shown in Table 2. All variables are significant and all them has the expected sings, according the theoretical framework. And the adjustment of the model is pretty good, since the values of the coefficients are: $\mathrm{R}=0.716$, $\mathrm{R}$ squared $=0.512$, R-squared-Adjusted $=0.469$. The correspondent equations for these results are reflected on Equations (1) and (2)

$Y=0,788+0.340 X_{1}+0.486 X_{2}+0.164 X_{3}-0.162 X_{4}$

$Y=0.456 X_{1}+0.424 X_{2}+0.213 X_{3}-0.220 X_{4}$ 
Being:

$\mathrm{Y}=$ Concern on future labor integration

$\mathrm{X} 1=$ Attitude towards learning

$\mathrm{X} 2=$ Teachers attitude towards motivation

$\mathrm{X} 3=$ Attitude towards educative innovation

$\mathrm{X} 4=$ ICTs for motivation at classroom

Table 2. Regression analysis results

\begin{tabular}{|l|c|c|c|c|c|}
\hline \multirow{2}{*}{} & \multicolumn{2}{|c|}{$\begin{array}{c}\text { No Standard } \\
\text { Coefficients }\end{array}$} & Standard \\
\cline { 2 - 5 } & Beta & $\begin{array}{c}\text { Standard } \\
\text { error }\end{array}$ & toefficients & Significance \\
\hline (Constant) & 0.788 & 0.615 & & 1.281 & 0.208 \\
\hline I enjoy learning & 0.340 & 0.089 & 0.456 & 3.819 & 0.000 \\
\hline $\begin{array}{l}\text { I'm motivated by } \\
\text { teachers who do } \\
\text { innovative activities in } \\
\text { class }\end{array}$ & 0.486 & 0.141 & 0.424 & 3.448 & 0.001 \\
\hline $\begin{array}{l}\text { I feel better in class if } \\
\text { the faculty uses new } \\
\text { technologies }\end{array}$ & 0.164 & 0.105 & 0.213 & 1.561 & 0.126 \\
\hline $\begin{array}{l}\text { Using tablets or } \\
\text { computers in class } \\
\text { motivates me }\end{array}$ & -0.162 & 0.105 & -0.220 & -1.539 & 0.132 \\
\hline
\end{tabular}

*** P-value $<0.000$

Source: authors' own elaboration.

The results confirm that there is a relation among the concern of secondary's education students about their possibilities of getting a job and their scholar performance, particularly in relation to the ICTs and innovation at school.

The dependent variable should be explained by means of the independent ones, according academic literature. That is to say, attitude of students, attitude of teachers towards innovation (in general terms) and education issues are important variables, as well as the motivation for the use of ICTs, for improving performance and, as a consequence, the possibilities of getting a job in the next future. 


\section{Discussion}

The only variable which has shown a relatively surprising sing is the last one "Using tablets or computers in class motivates me", which is negatively correlated to the dependent variable. Nevertheless there is a reasonable explanation for this sign, because the innovation at the class room is very well considerate (see the values and significance of the variables I'm motivated by teachers who do innovative activities in class, and I feel better in class if the faculty uses new technologies in Table 2). That is why those students more concerned with the importance of learning for the future are more focused on the content of the class than on the instruments, like computers or tables, which explain why they don't feel more motivated using these devices during the class. But they will probably use for study at home or at the library (that is a consistent conclusion arose from the responses to the other questions).

\section{Conclusions}

The main hypothesis of this work regarding the relationship between the possibilities of finding a job and the motivation of middle school students, through the application of innovative educational methods, cannot be rejected, both attending to the review of the academic literature and to the results obtained with the studies made from the primary data gotten specifically for this work.

The promotion of educational innovation in secondary education classrooms not only motivates students and helps them achieve better performance, but also makes them see the importance of a good curricular performance to achieve a job in the future. 


\section{Limitations of this research}

The main limitation of this work is that which is usually present in the study of a case: the sample is limited to a specific academic center. However, regardless of the possibility of generalization of results, we consider that this is valuable, not only because of what it implies for decision-making in the educational management of the center itself, but also because they are in line with the results of other investigations in the academic literature and because, as has been pointed out in previous sections, the characteristics of the center analyzed suggest the possibility of generalization.

Taking account these comments, results achieved with this research should be understood as a case study more than a general conclusion.

The future lines of research point, first of all, towards trying to generalize the results obtained, trying to extend the sample to other educational centers.

\section{References}

Atkinson J.W. (1964), An introduction to motivation, Van Nostrand, Princeton, NJ.

Bandura A. (1986), Social foundations of thought and action. A social cognitive theory, Prentice-Hall, Englewood Cliffs, NJ.

Bandura A. (2001), Social cognitive theory. An agentic perspective, „Annual Review of Psychology”, vol. 52, pp. 1-26.

Bandura A. (2005), The primacy of self-regulation in health promotion, „Applied Psychology. An International Review", vol. 54 no. 2, pp. 245-254.

Bandura A. (2006), Going global with social cognitive theory. From prospect to paydirt, in: Applied psychology. New frontiers and rewarding careers, Donaldson S.I., Berger D.E., Pezdek K. (eds.), Lawrence Erlbaum, Mahwah, NJ, pp. 53-79.

D’Ancona C., Ángeles M. (1999), Metodología cuantitativa. Estrategias y técnicas de investigación social, Editorial Síntesis, Madrid.

Bryan R.R., Glynn S.M., Kittleson J.M. (2011), Motivation, achievement, and advanced placement intent of high school students learning science, ,Science Education”, vol. 95 no. 6, pp. 1049-1065.

Gagne R.M. (1965), The conditions of learning, Holt, Rinehart and Winston, New York.

Gagne R.M. (1972), Domains of learning, „Interchange”, vol. 3 no. 1, pp. 1-8. 


\section{Javier NOVO-HERNANZ, Xose PICATOSTE}

Gagne R.M. (1984), Learning outcomes and their effects, „American Psychology”, vol. 39 no. 4, pp. 377-385.

Gagne R.M., Briggs L.J. (1979), Principles of instructional design, Holt, Rinehart and Winston, New York.

García Sedeño M.A., Barbero García M.I., Avila Carretero I., García Tejera M.C. (2003), La motivación laboral de los jóvenes en su primer empleo, „Psicothema”, vol. 15 no. 1, pp. 109-113.

Hyland N., Kranzow J. (2011), Faculty and student views of using digital tools to enhance self-directed learning and critical thinking, „International Journal of Self-Directed Learning”, vol. 8 no. 2, pp. 11-27.

Jacinto C. (2008), Los dispositivos recientes de empleo juvenile. Institucionalidades, articulaciones con la educación formal y socialización laboral, „Revista de Trabajo”, vol. 4 no. 6, pp. 123-142.

Novo-Corti I., Varela-Candamio L., Ramil-Díaz M. (2013), E-learning and face to face mixed methodology. Evaluating effectiveness of e-learning and perceived satisfaction for a microeconomic course using the Moodle platform, „Computers in Human Behavior”, vol. 29 no. 2, pp. 410-415.

Pajares F., Schunk D.H. (2001), Self-beliefs and school success. Self-efficacy, self-concept, and school achievement, in: Self-perception, Riding R., Rayner S. (eds.), Ablex Publishing, London, pp. 239-266.

Pérez P.E. (2013), Empleabilidad, motivación por trabajar y políticas de empleo para jóvenes en Argentina, „Cuestiones de Sociología”, no. 9, pp. http://ri.conicet.gov.ar/bitstream/handle/11336/3887/Empleabilidad_motivaci_n_por_trabajar_y_politi cas_de_empleo_pra_j_venes_en_Argentina.pdf?sequence=1 [31.05.2019].

Prensky M. (2001), Digital natives, digital immigrants. Part 1, „On the Horizon”, vol. 9 no. 5, pp. 1-6.

Prensky, M. (2011), Enseñar a nativos digitales, Ediciones SM, Madrid.

Schunk D.H., Pintrich P.R., Meece J.L. (2008), Motivation in education, 3rd ed., Pearson, Upper Saddle River, NJ.

Sini B., Muzzulini B., Schmidt S., Tinti C. (2018), School motivation. A comparison between Kenya and Italy, „The Journal of Educational Research”, vol. 111 no. 6, pp. 1-10. 